\title{
EFEK DURASI WAKTU EKSTRAKSI DAN FRAKSINASI TERHADAP AKTIVITAS ANTIOKSIDAN DAUN BAKAU API-API PUTIH (Avicennia marina)
}

\section{Effect of Extraction Duration and Fractionation on Antioxidant Activity of Grey Mangrove Leaves (Avicennia marina)}

\author{
Safrina Dyah Hardiningtyas ${ }^{1 *}$, Sri Purwaningsih ${ }^{1}$, dan Ekowati Handharyani ${ }^{2}$ \\ 1 Departemen Teknologi Hasil Perairan, Fakultas Perikanan dan IImu Kelautan, Institut Pertanian Bogor, \\ Jalan Agatis, Bogor, Jawa Barat, Indonesia \\ ${ }^{2}$ Departemen Klinik, Reproduksi, dan Patologi, Fakultas Kedokteran Hewan, Institut Pertanian Bogor. \\ Jalan Agatis, Bogor, Jawa Barat, Indonesia \\ *Korespondensi Penulis: safrina_dyah@apps.ipb.ac.id
}

Diterima: 24 Juli 2019; Direvisi: 21 Agustus 2019; Disetujui: 17 Januari 2020

\begin{abstract}
ABSTRAK
Api-api putih (Avicennia marina) merupakan salah satu jenis bakau yang melimpah di Indonesia dan dapat dimanfaatkan sebagai sumber antioksidan alami. Penelitian ini bertujuan untuk menentukan pengaruh waktu ekstraksi dan fraksinasi daun $A$. marina terhadap aktivitas antioksidannya. Serbuk daun $A$. marina dimaserasi dengan pelarut etil asetat pada durasi waktu ekstraksi selama 1, 2, 3, dan 4 hari. Sementara itu, fraksinasi ekstrak etil asetat dilakukan dengan kolom kromatografi secara isokratik. Aktivitas antioksidan dari ekstrak kasar dan fraksi-fraksi dianalisis dengan metode DPPH (1,1-diphenyl-2-picrylhydrazyl). Hasil analisis menunjukkan perlakuan selama satu hari merupakan durasi waktu ekstraksi terbaik untuk mendapatkan rendemen ekstrak $(1,65 \pm 0,01$ $\%)$ dengan aktivitas antioksidan tertinggi $\left(\mathrm{IC}_{50} 186,67 \pm 2,82 \mathrm{ppm}\right)$. Eluen pengembang terbaik untuk fraksinasi ekstrak etil asetat adalah campuran eluen etil asetat: n-heksana (3:7), yang menghasilkan delapan fraksi. Namun, fraksinasi menurunkan aktivitas antioksidan pada fraksi-fraksi, dibandingkan dengan ekstraknya. Hal ini diduga disebabkan oleh efek sinergis antar senyawa dalam ekstrak. Penelitian lebih lanjut dapat dilakukan untuk isolasi senyawa aktif yang terdapat ekstrak etil asetat daun bakau $A$. marina.
\end{abstract}

KATA KUNCI : Avicennia marina, antioksidan, bakau, fraksinasi

ABSTRACT

Grey mangrove (Avicenia marina) is one of the abundant types of mangrove in Indonesia, which can be used as a natural antioxidant source. This study aimed to determine the effect of extraction duration and fractionation on the antioxidant activity of $\underline{A}$. Marina leaves. $\underline{A}$. marina leaves powder was macerated by ethyl acetate solvent for 1, 2, 3, and 4 days. Meanwhile, fractionation was carried out using column chromatography with an isocratic method. The antioxidant activity of crude extracts and fractions was analyzed by DPPH (1,1-diphenyl-2-picrylhydrazyl) method. The result showed that oneday treatment was the optimum extraction duration to obtain the extract's yield $(1.65 \pm 0.01 \%)$ with the highest antioxidant activity $\left(I C_{50} 186.67 \pm 2.82 \mathrm{ppm}\right)$. The best eluent in fractionation was a mixture of ethyl acetate: $n$-hexane (3:7) eluents, which produced eight fractions. However, fractionation reduced the antioxidant activity of fractions, compared to the crude extract. This might have happened because of the synergistic effect among compounds in the extract. Further research can be carried out to isolate the active compounds in the $\underline{A}$. marina leaves extract.

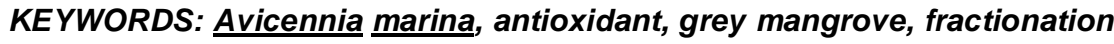

\section{PENDAHULUAN}

Bakau merupakan tumbuhan yang umum terdapat di wilayah pesisir laut atau daerah pasang surut. Biota ini hidup pada kondisi tanah berlumpur dan anerobik (Duke et al., 2010). Api-api putih (Avicennia marina) adalah salah satu jenis bakau yang tersebar dan melimpah di Indonesia (Noor, Khazali, \& Syadipura, 2006). Daun A. marina telah dimanfaatkan oleh masyarakat pesisir sebagai bahan pangan dan obatobatan untuk mengobati beberapa jenis penyakit, seperti hepatitis, aphrodisiac, kusta, cacar, rematik, 
bisul, dan obat luka bakar (Bandaranayake, 2002; Noor et al., 2006). Aktivitas biologis dari daun biota ini terkait dengan kandungan metabolit sekundernya. Behbahani et al. (2018) menyatakan bahwa kandungan fitokimia dari daun $A$. marina adalah alkaloid, tanin, saponin, plavon, dan glikosida. Daun $A$. marina berpotensi sebagai sumber antioksidan alami untuk mencegah terjadinya penyakit degeneratif, seperti penyakit liver, diabetes, kardiovaskular, dan neurodegeneratif. Penyakit-penyakit ini secara umum disebabkan oleh kerusakan sel akibat peroksidasi lipid dari stres oksidatif dalam tubuh pada ketidakseimbangan konsentrasi radikal bebas dan zat antioksidan (Sen, Chakraborty, Sridhari, Reddy, \& De, 2010).

Riset yang dilakukan oleh Hardiningtyas, Purwaningsih, dan Handharyani (2014) telah melaporkan ekstrak etil asetat daun $A$. marina memiliki aktivitas antioksidan yang lebih tinggi dibandingkan dengan ekstrak metanol dan ekstrak nheksana, serta efek hepatoprotektif pada tikus yang diinduksi $\mathrm{CCl}_{4}$, namun dengan rendemen yang rendah $(1,28 \pm 0,11 \%)$. Hasil ekstraksi dapat dipengaruhi oleh beberapa faktor, antara lain jenis pelarut dan waktu ekstraksi (Khopkar, 2003). Ekstraksi akan memisahkan suatu komponen yang aktif dari jaringan tanaman atau hewan menggunakan pelarut tertentu, dengan durasi perlakuannya merupakan parameter penting dalam menentukan jumlah energi dan biaya (Chew et al., 2011; Visht \& Chaturvedi, 2012). Selain itu, fraksinasi juga merupakan tahapan yang penting, sebagai teknik pemisahan senyawa bioaktif dalam ekstrak kasar, untuk meningkatkan aktivitas biologisnya (Chandel et al., 2019; Saraswaty et al., 2017; dan Yang, Yan, Huang, \& Fu, 2014).

Berdasarkan pentingnya optimalisasi pada proses ekstraksi dan fraksinasi, maka penelitian ini bertujuan untuk menentukan pengaruh waktu ekstraksi dan fraksinasi terhadap aktivitas antioksidan dari daun $A$. marina, dalam mendapatkan rendemen serta bioaktivitas antioksidan yang optimal. Sementara itu, proses fraksinasi yang dilakukan dapat memberikan petunjuk awal, dalam penentuan strategi yang tepat untuk isolasi senyawa aktif dari daun $A$. marina.

\section{BAHAN DAN METODE}

\section{Bahan}

Bahan utama yang digunakan adalah daun $A$. marina yang diperoleh dari Kawasan Hutan bakau Blanakan, Subang. Bahan lain yang digunakan adalah distilat etil asetat teknis, metanol p.a (Merck), etil asetat p.a (Merck), n-heksana (Merck), kloroform (Merck), aseton (Merck), DPPH 1,1-diphenyl-2- picrylhydrazyl (Sigma), butylated hydroxytoluene (BHT), vitamin C (vitamin super ester C), dan plat silika gel $60 \mathrm{~F}_{254}$ (Merck).

\section{Metode}

\section{Ekstraksi daun A. marina}

Air bersih dipergunakan untuk mencuci daun dari kotoran. Setelah itu, daun dijemur selama 4 hari di bawah sinar matahari hingga kering. Daun yang sudah kering dijadikan bentuk serbuk dengan mesin penepung berukuran saringan 100 mesh. Bubuk daun disimpan dalam wadah gelap dan suhu ruang hingga digunakan.

Bubuk daun kering dimaserasi dalam pelarut etil asetat (perbandingan berat sampel dan volume pelarut sebesar 1:5), dengan variabel durasi waktu yang menggunakan Rancangan Acak Lengkap (RAL) selama 1, 2, 3, dan 4 hari. Maserat dari masingmasing perlakuan dipisahkan dengan metode filtrasi menggunakan kertas saring. Filtrat kemudian dievaporasi dalam vacuum rotary evaporator (Buchi R-210) pada suhu $40^{\circ} \mathrm{C}$ hingga diperoleh ekstrak kasar berbentuk pasta. Ekstrak ini ditimbang untuk mendapatkan rendemen ekstraknya.

\section{Fraksinasi ekstrak daun A. marina}

Fraksinasi dilakukan berdasarkan Sarker, Latif, \& Gray (2006), melalui dua tahapan. Tahap pertama adalah penentuan eluen terbaik dengan menggunakan kromatografi lapis tipis (KLT). Tahap selanjutnya adalah pemisahan senyawa bioaktif pada ekstrak kasar dengan kolom kromatografi secara isokratik.

Penentuan eluen terbaik dengan kromatografi lapis tipis (KLT)

Larutan ekstrak (40 mg/mL) ditotolkan pada garis awal plat silika gel $60 \mathrm{~F}_{254}$, kemudian dimasukkan dalam chamberberisi eluen pengembang tunggal yang jenuh. Eluen pengembang tunggal pada penelitian ini adalah n-heksana, kloroform, etil asetat, aseton, dan metanol. Plat silika gel diinkubasi dalam chamber hingga eluen mencapai garis akhir. Pengamatan di bawah lampu UV dilakukan untuk mendeteksi eluen tunggal yang memiliki kemampuan terbaik dalam memisahkan spot. Eluen pengembang tunggal terbaik selanjutnya dikombinasikan dengan berbagai perbandingan. Plat silika gel yang telah ditotolkan larutan ekstrak diinkubasi pada beberapa kombinasi eluen pengembang, untuk menemukan yang dapat menghasilkan spot-spot bulat dan terpisah. Eluen terbaik selanjutnya digunakan dalam pemisahan senyawa bioaktif menggunakan kromatografi kolom. 


\section{Pemisahan dengan kromatografi kolom}

Pemisahan senyawa bioaktif dilakukan dengan metode isokratik kromatografi kolom menggunakan fasa diam serbuk silika gel $60 \mathrm{~F}_{254}$. Pada tahapan awal, serbuk silika gel direndam dalam eluen pengembang terpilih, dimasukkan ke dalam kolom, dan dijenuhkan selama 24 jam. Sebanyak $3 \mathrm{~mL}$ larutan ekstrak etil asetat $(666,67 \mathrm{mg} / \mathrm{mL})$ dimasukkan ke dalam kromatografi kolom tersebut, kemudian dialiri eluen secara simultan. Larutan yang keluar dari kolom ditampung pada tabung reaksi $5 \mathrm{~mL}$, dengan total larutan yang ditampung sebanyak $\pm 130 \mathrm{~mL}$. Larutan pada masing-masing tabung reaksi dievaporasi sehingga dihasilkan residu fraksi. Pengujian KLT dilakukan terhadap tiap fraksi untuk melihat profil spot yang dihasilkan. Apabila suatu fraksi memiliki kesamaan pola kromatogram atau spot, maka dilakukan penggabungan fraksi. Beberapa fraksi gabungan selanjutnya diuji aktivitas antioksidan menggunakan metode DPPH.

\section{Pengujian aktivitas antioksidan}

Pengujian aktivitas antioksidan dilakukan terhadap ekstrak kasar dan semua fraksi dengan menggunakan modifikasi metode DPPH yang dilakukan oleh Hanani, Mun'im, dan Sekarini (2005). Sampel dilarutkan dalam etil asetat pada konsentrasi 50, 100, 150, 200, dan $300 \mathrm{ppm}$. Kontrol positif yang dipergunakan adalah butylated hydroxytoluene $(\mathrm{BHT})$ dan vitamin super ester $C$, pada konsentrasi $2,4,6$, 8 , dan $10 \mathrm{ppm}$. Sebnayak 4,5 $\mathrm{mL}$ larutan sampel atau kontrol positif dicampurkan dengan $0,5 \mathrm{~mL}$ larutan DPPH $1 \mathrm{mM}$ dalam metanol, kemudian diinkubasi pada suhu $37^{\circ} \mathrm{C}$ selama 1 jam. Absorbasi larutan dan blanko diukur dengan spektofotometer UV-Vis (Labomed RS UV2500) pada panjang gelombang 517 $\mathrm{nm}$. Aktivitas antioksidan masing-masing sampel dinyatakan dengan persentase penghambatan radikal bebas melalui rumus (Molyneux, 2004):

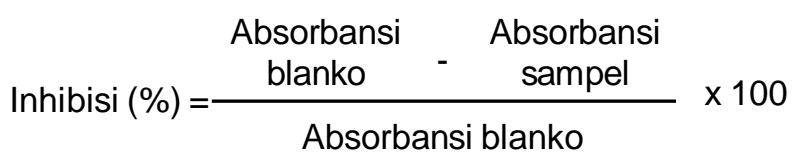

Konsentrasi larutan sampel yang dibutuhkan untuk mereduksi DPPH sebesar $50 \%$ atau disebut $\mathrm{IC}_{50}$ (Inhibitor Concentration 50\%) diperoleh dari persamaan regresi linear antara konsentrasi larutan sampel $(x)$ dan persen inhibisi dari larutan sampel (y). Pengujian ini dilakukan sebanyak tiga kali ulangan.

\section{Pengolahan Data}

Pengolahan data secara statistik dilakukan untuk mengetahui perbedaan rendemen ekstrak dan aktivitas antioksidan dari tiap-tiap perlakuan durasi ekstraksi. Analisis statistik yang dipergunakan adalah ANOVA (Analysis of Variance) pada perangkat lunak SPSS. Pengujian lanjut Duncan dilakukan pada hasil ANOVA yang berbeda nyata di selang kepercayaan $95 \%$.

\section{HASIL DAN PEMBAHASAN}

\section{Pengaruh Durasi Waktu Ekstraksi terhadap Rendemen dan Aktivitas Antioksidan}

Gambar 1 menunjukkan durasi waktu mempengaruhi rendemen ekstrak yang dihasilkan secara nyata $(p<0,05)$. Uji lanjut Duncan menunjukkan perbedaan hasil dari perlakuan satu dan empat hari secara nyata $(p<0,05)$, yang memiliki rendemen

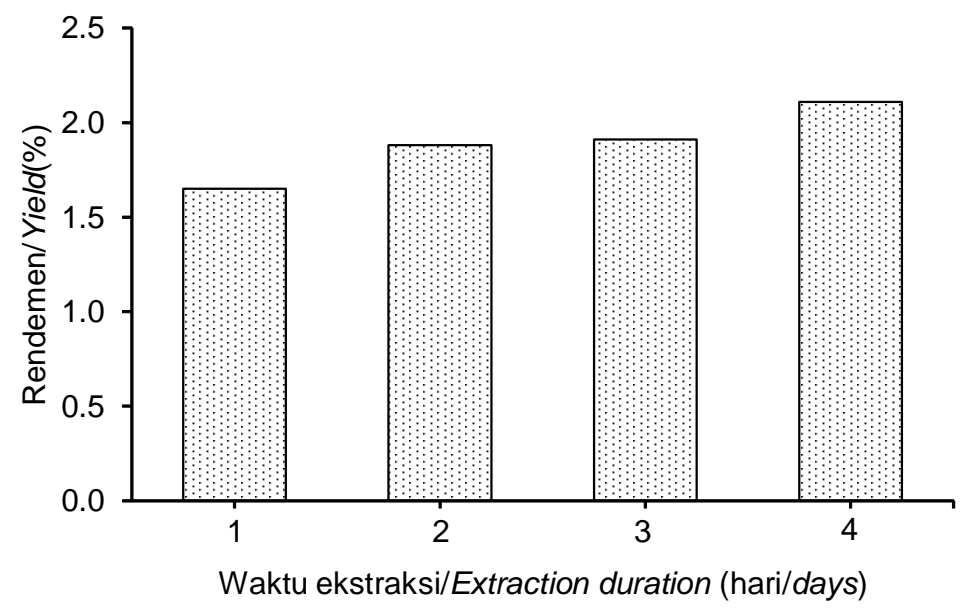

Gambar 1. Rendemen ekstrak etil asetat daun A. marina dengan waktu ekstraksi yang berbeda Figure 1. The yield of ethyl acetate extract of $\underline{A}$. marina leaves with different duration of extraction 
terkecil dan terbesar. Sementara itu, perlakuan antara dua dan tiga hari tidak menunjukkan perbedaan yang nyata $(p>0,05)$. Rendemen ekstrak meningkat seiring dengan durasi waktu. Ekstraksi selama 4 hari menghasilkan rendemen ekstrak yang paling banyak. Meskipun demikian, Gambar 2 menunjukkan bahwa durasi waktu ekstraksi memberikan pengaruh yang nyata $(p<0,05)$ terhadap aktivitas antioksidan.

Pertambahan rendemen seiring dengan durasi waktu ekstraksi dapat terjadi karena adanya peningkatan interaksi antara pelarut dan sampel (Henriques, Silva, \& Rocha, 2007). Efisiensi ekstraksi meningkat dengan durasi waktu dalam rentang tertentu, hingga mencapai kesetimbangan konsentrasi komponen aktif yang berada di luar dan di dalam Sampel (Zhang, Lin, \& Ye, 2018). Sementara itu, akivitas antioksidan tertinggi ditunjukkan oleh perlakuan ekstrak selama satu hari, meskipun masih tergolong lemah (150-200 ppm). Molyneux (2004) menggolongkan 4 daya antioksidan berdasarkan nilai $\mathrm{IC}_{50}$, yaitu lemah (150-200 ppm), sedang (100-150 ppm), kuat (50-100 ppm), dan sangat kuat (kurang dari $50 \mathrm{ppm}$ ). Penurunan aktivitas pada peningkatan durasi waktu ekstraksi juga ditemukan oleh Hou, Zhang, Chen, dan Luo (2016), yang menunjukkan bahwa ekstraksi selama lebih dari tiga hari menyebabkan komponen aktif daun Melaleuca bracteata mengalami penurunan yang drastis pada kapasitas penangkapan radikal DPPH.

Penurunan aktivitas antioksidan pada penambahan durasi waktu ekstraksi diduga disebabkan oleh kerusakan komponen bioaktif selama proses ekstraksi. Garcia-Salas, Morales-Soto, SeguraCarretero, dan Fernández-Gutiérrez (2010) dan Hou et al. (2016) menerangkan bahwa komponen aktif yang berasal dari daun dapat mengalami oksidasi spontan apabila dilakukan inkubasi/maserasi yang berkepanjangan. Hasil penelitian Chew et al. (2011) serta Rahmawati dan Hayashi (2012) menunjukkan durasi waktu ekstraksi yang lama menyebabkan penurunan aktivitas penangkapan radikal bebas dan kadar total fenolik pada ekstrak. Kuljarachanan, Devahastin, dan Chiewchan (2009) menyatakan bahwa penurunan aktivitas antioksidan dapat disebabkan oleh enzim endogen dalam jaringan tanaman yang mendegradasi senyawa fenolik dalam ekstrak Centella asiatica.

\section{Fraksinasi Ekstrak Daun A. marina}

Fraksinasi dilakukan terhadap ekstrak daun yang diperoleh dari perlakuan waktu ekstrasi selama satu hari. Eluen pengembang terbaik yang ditemukan untuk memisahkan senyawa pada ekstrak kasar adalah campuran antara pelarut etil asetat dan n-heksana, dengan perbandingan 3:7 (Gambar 3). Selanjutnya, proses fraksinasi ekstrak menggunakan kromatografi kolom dan eluen serupa menghasilkan 8 fraksi, yaitu $\mathrm{F} 1(0,05 \mathrm{~g}), \mathrm{F} 2(0,15 \mathrm{~g}), \mathrm{F} 3(0,21 \mathrm{~g}), \mathrm{F} 4(0,29 \mathrm{~g})$, F5 $(0,199 \mathrm{~g}), \mathrm{F} 6(0,13 \mathrm{~g}), \mathrm{F} 7(0,11 \mathrm{~g})$, dan F8 $(0,11 \mathrm{~g})$.

Pemisahan pada KLT dan kromatografi kolom menunjukkan 8 fraksi dengan nilai Rf yang berbeda. Sistem eluen yang merupakan pelarut non-polar ( $n$ heksana) dan semi-polar (etil asetat) memberikan dugaan bahwa fraksi-fraksi ini mengandung senyawasenyawa non-polar hingga kepolaran menengah. Golongan senyawa-senyawa ini, jika dibandingkan dengan hasil penelitian terhadap ekstrak etil asetat dari daun $A$. marina dan anting-anting (Acalypha Indica Linn) yang dilakukan oleh Sriwahyuni (2010) dan Hardiningtyas et al. (2014), dapat diduga

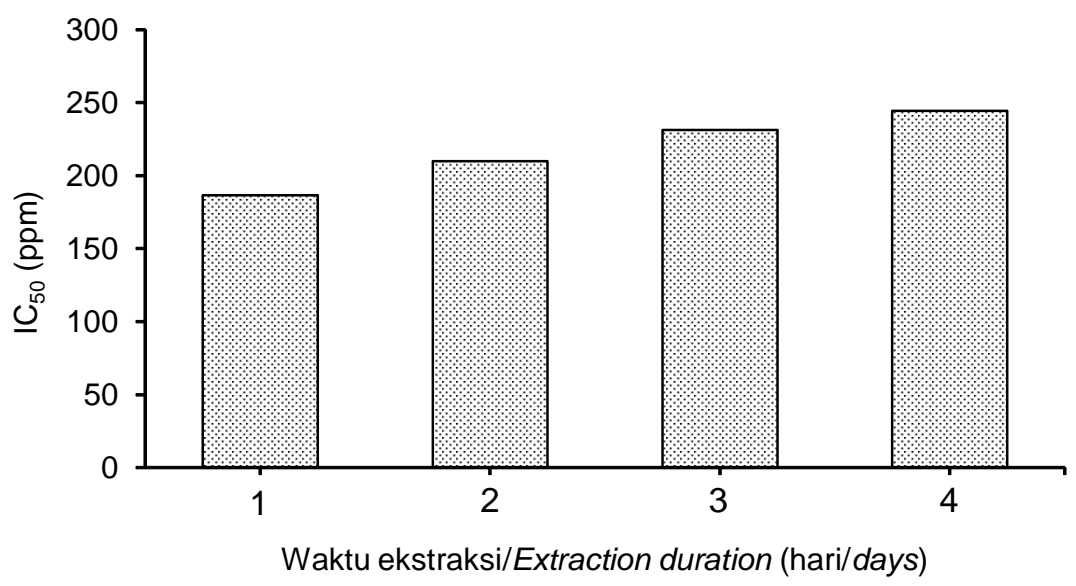

Gambar 2. Aktivitas antioksidan ekstrak etil asetat daun A. marina dengan perlakuan durasi ekstraksi yang berbeda

Figure 2. Antioxidant activity of the ethyl acetate extract of $\underline{A}$. marina leaves with different duration of extraction 


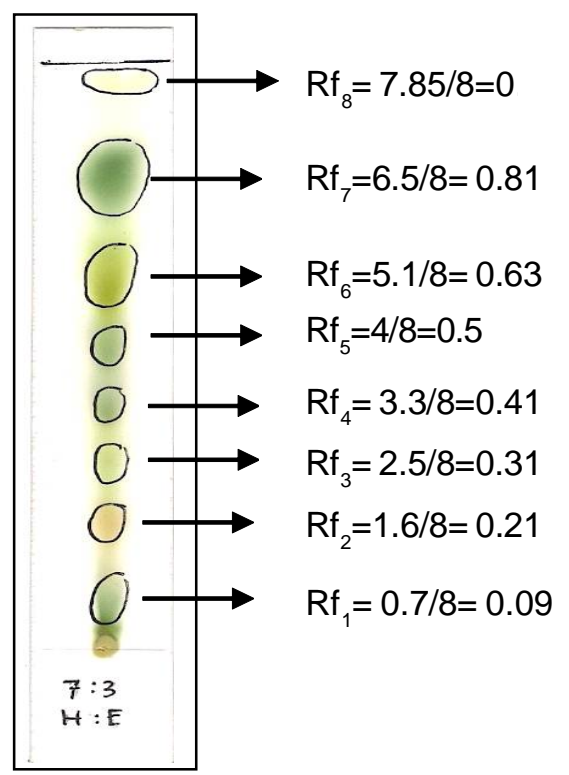

Gambar 3. Fraksinasi ekstrak daun A. marina menggunakan KLT dengan eluen etil asetat: n-heksana (3:7)

Figure 3. Fractination of ethyl acetate extract from $\underline{A}$. marina leaves using TLC with ethyl acetate : $n$ hexane (3: 7) eluent

merupakan senyawa golongan flavonoid, steroid, atau triterpenoid.

\section{Aktivitas Antioksidan Fraksi dari Ekstrak Daun A. marina}

Aktivitas antioksidan ekstrak kasar dan fraksi-fraksi dari ekstrak daun disajikan pada Gambar 4. Perbedaan yang nyata $(p<0,05)$ terdeteksi antara daya antioksidan dari ekstrak kasar dan beberapa fraksinya. Ekstrak kasar secara umum memiliki nilai $\mathrm{IC}_{50}$ yang lebih rendah dibandingkan dengan fraksi-fraksi hasil pemurnian, terkecuali terhadap F1 dan F2. Daya aktivitas antioksidan dari ekstrak kasar tidak berbeda nyata $(p>0,05)$ dengan kedua fraksi awal tersebut. Fraksi lain (F3-F8) memiliki nilai $I_{50}$ yang lebih besar secara nyata $(p<0,05)$. Sementara itu, kontrol positif $\mathrm{BHT}$ dan vitamin $\mathrm{C}$ memiliki aktivitas antioksidan yang kuat, dengan nilai $I C_{50}$ masing-masing sebesar 5,86 dan 8,26 ppm.

F1 dan F2 merupakan fraksi paling potensial dibandingkan dengan lainnya, walaupun tergolong memiliki aktivitas antioksidan yang lemah. Penelitian lebih lanjut dapat dilakukan pada dua fraksi ini, untuk isolasi dan identifikasi senyawa-senyawa aktifnya. Nilai IC ${ }_{50}$ pada ekstrak dan fraksi diduga karena ada sinergisme antar senyawa aktif yang terkandung pada

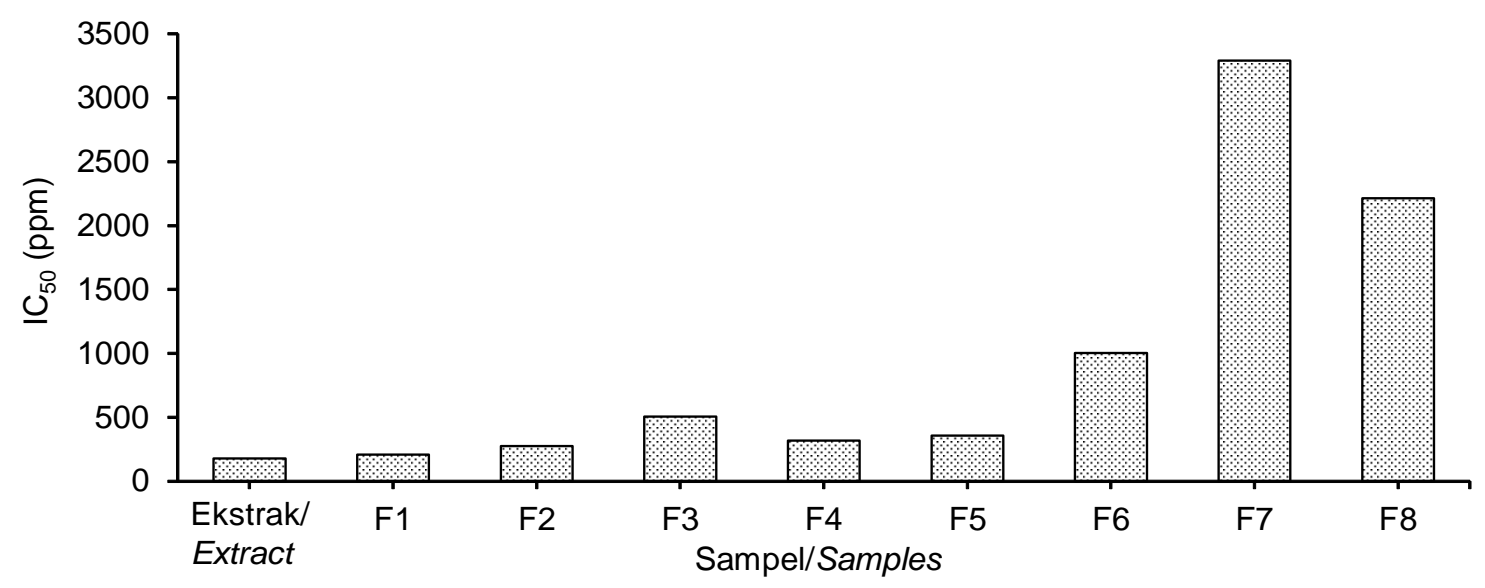

Gambar 4. Aktivitas antioksidan ekstrak kasar dan fraksi-fraksi dari daun A. marina Figure 4. Antioxidant activity of crude extracts and fractions of $\underline{A}$. marina leaves 
ekstrak, sehingga aktivitasnya menurun ketika dipisahkan. Moure et al. (2001) menyatakan bahwa efektivitas antioksidan dari campuran komponen bioaktif sinergis lebih tinggi dibandingkan dengan aktivitas pada komponen tunggal. Hasil penelitian Santos, Santos, Gamboa, Zanoni, dan Furlan (2010) menunjukkan bahwa komponen flavonoid dan quinonemetida triterpen dari Maytenus ilicifolia memiliki efek sinergisme dalam menghasilkan aktivitas antioksidan. Mu, Kou, Zhu, dan Yu (2007) juga menyatakan bahwa efek neuroprotektif, aktivitas antioksidan, dan anti-inflamantori, dari kombinasi komponen flavonoid dan triterpenoid dengan perbandingan 4:1 dalam Ginkgo biloba lebih baik dibandingkan dengan komponen tunggalnya. Berdasarkan hal tersebut, dimungkinkan adanya efek sinergisme antara senyawa-senyawa pada ekstrak kasar, sehingga menghasilkan aktivitas antioksidan yang lebih baik.

\section{KESIMPULAN}

Durasi waktu ekstraksi berpengaruh terhadap rendemen dan aktivitas antioksidan daun $A$. marina. Lama waktu ekstraksi dapat meningkatkan rendemen ekstrak, namun menyebabkan penurunan aktivitas antioksidannya. Perlakuan selama satu hari merupakan durasi waktu ekstraksi terbaik yang menghasilkan aktivitas antioksidan tertinggi. Selain itu, proses fraksinasi ekstrak etil asetat menghasilkan 8 fraksi yang memiliki bioaktivitas berbeda. Penelitian yang lebih lanjut dapat dilakukan untuk isolasi dan identifikasi senyawa-senyawa aktif yang terdapat dalam ekstrak etil asetat daun A. Marina.

\section{DAFTAR PUSTAKA}

Bandaranayake, W. M. (2002). Bioactivities, bioactive compounds and chemical constituents of mangrove plants. Wetlands Ecology and Management, 10, 421452.. doi: 10.1023/A:1021397624349

Behbahani, B. A., Yazdi, F. T., Shahidi, F., Noorbakhsh, H., Vasiee, A., \& Alghooneh, A. (2018). Phytochemical analysis and antibacterial activities extracts of mangrove leaf against the growth of some pathogenic bacteria. Microbial Phatogenesis, 144, 225-232. doi:10.1016/j.micpath.2017.12.004.

Chandel, S. R., Kumar, V., Guleria, S., Sharma, N., Sourirajan, A., Khosla, P. K., Baumler, D. J., \& Dev, K. (2019). Sequential fractionation by organic solvents enhances the antioxidant and antibacterial activity of ethanolic extracts of fruits and leaves of Terminalia bellerica from North Western Himalayas, India. Pharmacognosy Journal, 11(1), 94-101. doi: 10.5530/pj.2019.1.17.
Chew, K. K., Ng, S.Y., Thoo, Y. Y., Khoo, M. Z., Wan, A. W. M., \& Ho, C. W. (2011). Effect of ethanol concentration, extraction time and extraction temperature on the recovery of phenolic compounds and antioxidant capacity of Centella asiatica extracts. International Food Research Journal, 18, 566-573.

Duke, N., Kathiresan, K., Salmo III, S.G., Fernando, E.S., Peras, J.R., Sukardjo, S., ....Ngoc Nam, V. (2010). Avicennia marina. The IUCN Red List of Threatened Species 2010: e.T178828A7619457. doi:10.2305/ IUCN.UK.2010-2.RLTS.T178828A7619457.en.

Garcia-Salas, P., Morales-Soto, A., Segura-Carretero, A., \& Fernández-Gutiérrez, A. (2010). Phenoliccompound-extraction systems for fruit and vegetable samples. Molecules, 15(12), 8813-8826. doi: 10.3390/molecules15128813.

Hanani, E., Mun'im, A., \& Sekarini, R. (2005). Identifikasi senyawa antioksidan dalam spons Callyspongia sp. dari Kepulauan Seribu. Majalah IImu Kefarmasian, 2(3),127-133.doi:10.7454/psr.v2i3.3389

Hardiningtyas, S. D., Purwaningsih, S., \& Handharyani, E. (2014). Aktivitas antioksidan dan efek hepatoprotektif daun bakau api-api putih. Jurnal Pengolahan Hasil Perikanan Indonesia, 17(1), 80-91.doi : 10.17844/jphpi.v17i1.8140

Henriques, M., Silva, A., \& Rocha J. (2007). Extraction and quantification of pigments from a marine microalga: a simple and reproducible method. In Mendez-Vilas, A. (Ed.), Communicating Current Research and Educational Topics and Trends in Applied Microbiology. Spain : Formatex.

Hou, W., Zhang, W., Chen, G., \& Luo, Y. (2016). Optimization of extraction conditions for maximal phenolic, flavonoid and antioxidant activity from Melaleuca bracteata leaves using the response surface methodology. PLoS One, 11(9), 1-16. doi:10.1371/journal.pone.0162139.

Khopkar SM. (2003). Konsep Dasar Kimia Analitik. Jakarta: UI-Press.

Kuljarachanan, T., Devahastin, S., \& Chiewchan, N. (2009). Evolution of antioxidant compounds in lime residues during drying. Food Chemistry, 113(4), 944949.doi:10.1016/j.foodchem.2008.08.026.

Molyneux, P. (2004). The use of stable free radical diphenylpicrylhydrazyl (DPPH) for estimating antioksidan activity. Songklanakarin Journal of Science Technology, 26(2), 211-219. doi : 10.1287/ isre.6.2.144

Moure, A., Cruz, J. M., Franco, D., Dominguez, J. M., Sineiro, J., Dominguez, H., Nuñez, M. J., \& Parajó, J.C. (2001). Natural antioxidants from residual sources. Food Chemistry, 72, 145-171. doi:10.1016/ S0308-8146(00)00223-5.

Mu, L., Kou, J., Zhu, D., \& Yu, B. (2007). Comparison of neuroprotective effects of flavonoids, terpenoids, and their combinations from Ginkgo biloba on ischemiareperfusion-injured mice. Pharmaceutical Biology, 45 (9), 728-733. doi:10.1080/13880200701575486 
Noor, Y. R., Khazali, M., \& Syadipura, I. N. N. (2006). Panduan Pengenalan Mangrove di Indonesia. Bogor: Wetlands International.

Rahmawati, S. I., \& Hayashi, N. (2012). The effects of batch reactor extraction on antioxidant activity from Scurulla atropurpurea. American Journal of Applied Sciences, 9 (3), 337-342. doi: 10.3844/ajassp.2012.337.342.

Santos, V. A. F. F., Santos, D. P., Gamboa, I. C., Zanoni, M. V. B., \& Furlan, M. (2010). Evaluation of antioxidant capacity and synergistic associations of quinonemethide triterpenes and phenolic substances from Maytenus ilicifolia (Celastraceae). Molecules, 15, 6956-6973. doi: 10.3390/molecules 15106956.

Saraswaty, V., Adnyana, I.K., Pudjiraharti, S., Mozef, T., Insanu, M., Kurniati, N. F., \& Rachmawati, H. (2017). Fractionation using adsorptive macroporous resin HPD-600 enhances antioxidant activity of Gnetum gnemon L. seed hard shell extract. J Food Sci Technol., 54(10), 33493357. doi: 10.1007/s13197-017-2793-3.

Sarker, S. D., Latif, Z., \& Gray, A. I. (2006). Natural Product Isolation. In Natural Products Isolation. (pp. 1-25). Humana Press. doi:10.1385/1-59259-955-9:1
Sen, S., Chakraborty, R., Sridhari, C., Reddy, Y. S. R., \& De, B. (2010). Free radicals, antioxidants, diseases and phytomedicines: Current status and future prospect. International Journal of Pharmaceutical Sciences Review and Research, 3(1), 91-100.

Sriwahyuni, S. (2010). Uji fitokimia ekstrak tanaman anting-anting (Acalypha Indica Linn) dengan variasi pelarut dan uji toksisitas menggunakan brine shrimp (Artemia salina Leach). Skripsi. Malang: Fakultas Sains dan Teknologi, Universitas Islam Negeri Maulana Malik Ibrahim.

Visht, S., \& Chaturvedi, S. (2012). Isolation of natural products. Current Pharma Research, 2(3), 584-599. doi: 10.33786/jcpr.2012.v02i03.014

Yang, X., Yan, F., Huang, S., \& Fu, C. (2014). Antioxidant activities of fractions from longan pericarps. Food Sci. Technol, Campinas, 34(2), 341-345, doi:10.1590/ S0101-20612014005000034.

Zhang, Q. W., Lin, L. G., \& Ye, W. C. (2018). Techniques for extraction and isolation of natural products: a comprehensive review. Chinese Medicine, 13(20), 426. doi: 10.1186/s13020-018-0177-x. 